\title{
Hydrogen sulphide poisoning: blood sulphide concentration and changes in haem metabolism
}

\author{
P Jäppinen, R Tenhunen
}

Hydrogen sulphide is still a potential hazard in several occupations ${ }^{12}$ and especially in sulphate pulp mills ( $\mathbf{P}$ Jäppinen, academic dissertation) and oil refineries. Blood sulphide may be used as an indicator of an excessive human hydrogen sulphide exposure. Fatal hydrogen sulphide concentrations are known. ${ }^{34}$ Blood sulphide concentrations have been determined before by ion selective electrodes combined with Conway microdiffusion cells but only high concentrations, $1.70-3.75 \mathrm{mg} / 1$, in fatal cases could be detected by this method. ${ }^{4}$ Recently, the method using ion selective electrodes has been improved by preconcentration of trapped sulphide in sodium hydroxide solution. ${ }^{5}$ This new application allows blood sulphide determinations at low concentrations and it is thus suitable also for non-fatal hydrogen sulphide poisonings.

Although decreased activities of haem synthesising enzymes, especially delta-aminolaevulinic acid synthase (ALA-S) and haem synthase (Haem-S) have been reported to occur in workers exposed to hydrogen sulphide and methyl mercaptan, ${ }^{6}$ it has been difficult to assess the severity of hydrogen sulphide poisoning in non-fatal cases. The aim of the present work was to evaluate the usefulness of blood sulphide concentrations and activities of haem synthesising enzymes in this respect.

\section{Material and methods}

There were 21 cases of acute hydrogen sulphide poisoning, mainly from sulphate pulp mills in Finland but also from a Finnish oil refinery. Three cases originated from a Swedish sulphate pulp mill. The subjects were exposed to hydrogen sulphide from about one minute up to 3.5 hours. On the basis of Draeger tube measurements made immediately after the accident it could be assumed that the hydrogen sulphide concentrations reached several hundred ppm if the subjects were unconscious and were most probably in the range of $20-200 \mathrm{ppm}$ in

Occupational Health Centre, Enso-Gutzeit Oy, SF55800 Imatra, Finland

P Jäppinen

Department of Clinical Chemistry, University of Helsinki, Helsinki

$\mathrm{R}$ Tenhunen cases with longer exposure followed by nausea and other typical symptoms.

A sample of $15 \mathrm{ml}$ of blood for blood sulphide was taken as soon as possible after the accident. Three blood samples were taken for analysis of the activities of haem synthesising enzymes. The first sample was taken immediately after the accident, the second after one week, and the third one month after the accident. The patients were examined by their plant physicians and clinical symptoms and signs were recorded.

The blood sulphide was analysed in the first samples according to the method of McAnalley et $\mathrm{al}^{4}$ and in the succeeding samples by the improved method. ${ }^{5}$ The activities of haem synthesising enzymes were determined by the methods described earlier. ${ }^{6}$

\section{Results}

There were six cases of hydrogen sulphide poisoning with initial blood samples collected in less than two hours and with subsequent blood samples to assess changes in haem metabolism (table 1). The estimated average duration of hydrogen sulphide exposure was 4.5 minutes and the mean of initial blood sulphide concentration was $75 \mu \mathrm{g} / 1$ (range 30-130 $\mu \mathrm{g} / 1$ ). Two subjects had been unconscious for 5-10 s, according to the supervisors and co-workers.

The ALA-S activity was lower in the subjects than in the controls already in the initial blood sample (cases: mean $0.21 \mathrm{pmol}$ of $\delta$-aminolaevulinic acid formed $/ \mathrm{h} \times 10^{6}$ reticulocytes, SD $0.09 ; 20$ control subjects: mean 0.50, SD $0 \cdot 18$ ) and decreased still in one week (mean $0 \cdot 19$, SD $0 \cdot 17$ ). The decrease was most prominent in the subjects with an initial blood sulphide concentration of more than $100 \mu \mathrm{g} / 1$. In three subjects the ALA-S activity was even more decreased one month after the accident but the main activity of the whole group did not differ from that found one week after the accident.

In the subjects presented in table 1 there were no major changes in the Haem-S activity, nor in the erythrocyte protoporphyrin concentration. The latter was, however, below the control range in the one day (cases: mean $348 \mathrm{nmol} / \mathrm{l}$ of erythrocytes, SD 81; controls: mean 450, SD 125) and one week samples (mean 415, SD 47).

There were 11 cases with hydrogen sulphide samples taken at least two hours after the accident 
Table 1 Blood sulphide concentration in workers with hydrogen sulphide poisoning

\begin{tabular}{|c|c|c|c|c|c|c|}
\hline $\begin{array}{l}\text { Case } \\
\text { No }\end{array}$ & $\begin{array}{l}\text { Sex } \\
M / F\end{array}$ & $\begin{array}{c}\text { Age } \\
(y)\end{array}$ & $\begin{array}{l}\text { Estimated } \\
\text { duration of } \\
\mathrm{H}_{2} \mathrm{~S} \text { exposure }\end{array}$ & $\begin{array}{l}\text { Durction of } \\
\text { unconsciousness }\end{array}$ & $\begin{array}{l}\text { Period to } \\
\text { blood sulphide } \\
\text { sampling }\end{array}$ & $\begin{array}{l}\text { Blood } \\
\text { sulphide } \\
(\mu g / l)\end{array}$ \\
\hline $\begin{array}{l}1 \\
2 \\
3 \\
4 \\
5 \\
6 \\
\text { Mean } \\
\text { SD }\end{array}$ & $\begin{array}{l}\mathbf{M} \\
\mathbf{M} \\
\mathbf{M} \\
\mathbf{M} \\
\mathbf{M} \\
\mathbf{M}\end{array}$ & $\begin{array}{l}33 \\
31 \\
50 \\
35 \\
53 \\
20\end{array}$ & $\begin{array}{l}1 \mathrm{~min} \\
5 \mathrm{~min} \\
1 \mathrm{~min} \\
5 \mathrm{~min} \\
7-8 \mathrm{~min} \\
7-8 \mathrm{~min}\end{array}$ & $\begin{array}{l}5-10 \mathrm{~s} \\
\text { No } \\
5-10 \mathrm{~s} \\
\text { No } \\
\text { No } \\
\text { No }\end{array}$ & $\begin{array}{l}25 \mathrm{~min} \\
25 \mathrm{~min} \\
1 \mathrm{~h} 45 \mathrm{~min} \\
1 \mathrm{~h} 30 \mathrm{~min} \\
1 \mathrm{~h} 30 \mathrm{~min} \\
1 \mathrm{~h} 30 \mathrm{~min} \\
1 \mathrm{~h} 11 \mathrm{~min} \\
36 \mathrm{~min}\end{array}$ & $\begin{array}{r}110 \\
130 \\
40 \\
80 \\
30 \\
60 \\
75 \\
39\end{array}$ \\
\hline
\end{tabular}

and with blood samples to assess possible changes in haem metabolism (cases 7-17, table 2). Three of these had initially been unconscious. In eight of the subjects in table 2 the ALA-S activity decreased in a week and the Haem-S activity decreased in seven subjects. There were no major changes in the erythrocyte protoporphyrin concentration in this group.

In four cases in table 2 (cases 7-10) the blood sulphide concentration was determined with the Conway microdiffusion cell method, with a detection limit of about $100 \mu \mathrm{g} / \mathrm{l}$. The sulphide concentration was below the detection limit in all these cases. In seven cases (cases 11-17) the sulphide concentration was determined with the improved method, with a detection limit of about $10 \mu \mathrm{g} / \mathrm{l}$, but the delay in collecting the samples may have affected the results.

Furthermore, there were four subjects with rather high or prolonged exposure, all being initially unconscious but with insufficient blood samples for assessing haem metabolism (cases 18-21, table 2). Three (cases 19-21) were Swedish, and the long shipping time of the sulphide samples may explain the low sulphide concentrations detected despite exposure with unconsciousness.

\section{Discussion}

Biochemical findings in subfatal hydrogen sulphide poisonings have rarely been reported. To achievei reliable results in blood sulphide analysis, the samplec has to be taken as soon as possible (not later than two음 hours) after the accident to be delivered and analysedwithout delay.

Although both ALA-S and Haem-S activities decrease after hydrogen sulphide poisoning, no definite conclusions on the degree of exposure can be\& drawn from the decreases of these activities. Further more, it should be noted that other sulphur compounds, mainly methyl mercaptan, may occur in pulp mills simultaneously with hydrogen sulphide with analogous effects on haem metabolism.

Analysis of blood sulphide is a way to single out hydrogen sulphide poisonings from other chemica $\overrightarrow{\vec{b}}$ exposures or attacks of ill health occurring at work 3 places. The analysis has also a forensic aspect Although the analyses are rather laborious, the blood? sulphide and haem analyses should be considered as practical means of diagnosing an acute hydrogen 3 sulphide poisoning.

This work was supported by the Finnish Worko

Table 2 Blood sulphide concentration in workers with hydrogen sulphide poisoning determined from samples collected two hou or more after exposure or with long delivery time (cases 18-21)

\begin{tabular}{|c|c|c|c|c|c|c|}
\hline $\begin{array}{l}\text { Case } \\
\text { No }\end{array}$ & $\begin{array}{l}\text { Sex } \\
M / F\end{array}$ & $\begin{array}{l}\text { Age } \\
(y)\end{array}$ & $\begin{array}{l}\text { Estimated } \\
\text { duration of } \\
\mathrm{H}_{2} \mathrm{~S} \text { exposure }\end{array}$ & $\begin{array}{l}\text { Duration of } \\
\text { unconsciousness }\end{array}$ & $\begin{array}{l}\text { Period to } \\
\text { blood sulphide } \\
\text { sampling }\end{array}$ & $\begin{array}{l}\text { Initial blood } \\
\text { sulphide } \\
(\mu \mathrm{g} / \mathrm{l})\end{array}$ \\
\hline $\begin{array}{l}7^{\star} \\
8^{\star} \\
9{ }^{\star} \\
10^{\star} \\
11 \\
12 \\
13 \\
14 \\
15 \\
16 \\
17 \\
18 \\
19 \\
20 \\
21\end{array}$ & $\begin{array}{l}\mathbf{M} \\
\mathbf{M} \\
\mathbf{M} \\
\mathbf{F} \\
\mathbf{M} \\
\mathbf{M} \\
\mathbf{M} \\
\mathbf{F} \\
\mathbf{M} \\
\mathbf{M} \\
\mathbf{M} \\
\mathbf{M} \\
\mathbf{M} \\
\mathbf{M} \\
\mathbf{M}\end{array}$ & $\begin{array}{l}25 \\
62 \\
47 \\
45 \\
54 \\
55 \\
31 \\
17 \\
29 \\
36 \\
20 \\
38 \\
54 \\
60 \\
45\end{array}$ & $\begin{array}{l}2-3 \mathrm{~min} \\
2 \mathrm{~min} \\
5 \mathrm{~min} \\
1 \mathrm{~h} \\
10 \mathrm{~min} \\
5 \mathrm{~min} \\
1.5 \mathrm{~h} \\
1.5 \mathrm{~h} \\
3 \mathrm{~h} \\
3.5 \mathrm{~h} \\
15 \mathrm{~min} \\
1-2 \mathrm{~min} \\
10 \mathrm{~min} \\
10 \mathrm{~min} \\
10 \mathrm{~min}\end{array}$ & $\begin{array}{l}\text { a few s } \\
2-3 \mathrm{~min} \\
\text { No } \\
\text { No } \\
\text { No } \\
\text { No } \\
\text { No } \\
\text { No } \\
\text { a few s } \\
\text { No } \\
\text { No } \\
2-3 \mathrm{~min} \\
5-15 \mathrm{~s} \\
5-15 \mathrm{~s} \\
5 \mathrm{~s}\end{array}$ & $\begin{array}{l}20 \mathrm{~min} \\
2 \mathrm{~h} \\
6 \mathrm{~h} \\
3 \mathrm{~h} \\
4 \mathrm{~h} \\
9 \mathrm{~h} \\
5.5 \mathrm{~h} \\
24 \mathrm{~h} \\
24 \mathrm{~h} \\
27 \mathrm{~h} \\
14 \mathrm{~h} \\
30 \mathrm{~min} \\
45 \mathrm{~min} \\
45 \mathrm{~min} \\
45 \mathrm{~min}\end{array}$ & $\begin{array}{r}<100 \\
<100 \\
<100 \\
<100 \\
100 \\
20 \\
<10 \\
20 \\
150 \\
300 \\
50 \\
60 \\
30 \\
<10 \\
<10\end{array}$ \\
\hline
\end{tabular}


Environment Fund. We thank Mr Henry Lindell, from Enso-Gutzeit Oy and Mrs Aila Åkerlund from the department of clinical chemistry, University of Helsinki, for their valuable work in carrying out the analyses. We are also indebted to Professor Heikki Savolainen from Institut Universitaire de Médecine et d'Hygiène du Travail in Lausanne for his many constructive remarks.

Requests for reprints to: Dr Paavo Jäppinen, EnsoGutzeit Oy, Occupational Health Centre, SF-55800 Imatra, Finland.

1 World Health Organisation. Environmental health criteria. No 19. Geneva: WHO, 1981.
2 Savolainen H. Nordiska expertgruppen for gränsvärdesdokumentation. 40. Dihydrogensulfid. Stockholm: Arbetarskyddsverket, 1981. (In Swedish.)

3 Winek CL, Collom WD, Wecht CH. Death from hydrogen sulphide fumes. Lancet 1968;i:1096.

4 McAnalley BH, Lowry WT, Oliver R, Garriott JC. Determination of inorganic sulfide and cyanide in blood using specific ion electrodes: application to the investigation of hydrogen sulfide and cyanide poisoning. J Anal Toxicol 1979;3:111-4.

5 Lindell H, Jäppinen P, Savolainen H. Determination of sulphide in blood with an ion-selective electrode by preconcentration of trapped sulphide in sodium hydroxide solution. Analyst 1988;113:839-40.

6 Tenhunen $R$, Savolainen $H$, Jäppinen P. Changes in haem synthesis associated with occupational exposure to organic and inorganic sulphides. Clin Sci 1983;64:187-91.

Accepted 3 July 1989 